\title{
Theories in Māori social work: Indigenous approaches to working with and for indigenous people
}

\author{
Awhina Hollis-English
}

\section{Abstract}

Māori social work practice has been developed upon a strong foundation of indigenous knowledge, theories and values. Theories can be used to validate social work practice and to build and enhance the engagement between workers and whānau. This article describes some Māori social work theories and how they have developed both within the social work world and that of neighbouring professions. A number of theories have been described by Māori social workers from across Aotearoa as the foundations for their social work practice. Theoretical discourse in the world of Māori social workers enables one to grow and develop their practice, leaning on ancestral knowledge and valuing the skills that are gained through understanding tikanga in a contemporary context. Through enhancing one's knowledge of Te Ao Māori and evidence-based practice, social workers can use, develop and create Māori theories in a social work context for the benefit of Māori whānau and communities.

\section{Introduction}

Māori social workers use theories to understand social contexts and to be guided in their interactions as professionals with people in their environments. Much like their non-Māori colleagues, Māori social workers theorise on a day-to-day basis and are constantly examining and reflecting upon their interactions. However, one's theoretical tendencies are often dependent upon one's cultural experiences and views of the world. This article describes theories that underpin the practice of many Māori social workers from around Aotearoa.

Social work in Aotearoa is founded upon theoretical approaches that have developed nationally and internationally, many of which are underpinned by Western value systems. These often Western-derived theories shape the social work profession and influence the practices and organisations where many Māori practitioners work and where many Māori families access support. While there are many factors influencing and impeding indigenous methods in Aotearoa, nonetheless, Māori social workers who identify with the Māori world have established evidence-based practices and are guided by Māori theories.

This article presents the results from research undertaken with Māori social workers from across Aotearoa, from as far south as Dunedin, to north of Auckland and across to the East Coast, Te Tai-rā-whiti. Twenty-six participants were involved in this research based around the question: 'what theories, approaches and models underpin your social work practice?' This paper is written by a Māori social worker, theorist and academic, and the various theories identified come from tangata whenua, Māori, bicultural, iwi, hapū and whānau social workers, with various views, values and norms, all of which are connected to Te Ao Māori. 
It should be noted that in a Māori context it is more likely that one does not label one's own practice with one key theory as such. This research identified that Māori social workers are more likely to respond by describing their connection to Te Ao Māori over and above the identification with a particular social work theory. This article explains Māori theories to those that are interested in learning about them and can be used by tangata whenua practitioners who live and breathe Te Ao Māori as a tool to explain to their colleagues the validity and depth of our practices and to build and enhance one's practices.

There are three stages to this article. The first is a literary analysis of Māori theories that inform contemporary Māori social work practice. This is followed by a discussion of the methodology and research design used for this project. The third part of the article presents the results and concludes with an analysis of the implications of this research for social work in Aotearoa New Zealand.

\section{Māori social work theories}

There are a variety of theoretical approaches that influence Māori social work practice that have been developing over the past 50 years. Te Ao Māori is not the only cultural influence on these theories, as it is clear that Māori social workers do not live 'on a desert island' isolated from Pākehā New Zealand society and other values, beliefs and theoretical systems. However, the key element that distinguishes Māori social work theories from others is that they are derived from Mātauranga Māori. They come from a particular worldview that is influenced by one's experiences of being connected to a whānau, hapū and iwi, being indigenous in Aotearoa and having embedded in one's ancestry, specific values and traditions belonging to that culture. Kaupapa Māori theory has been popularised as a theoretical approach for Māori social workers, researchers and educationalists over the past 20 years. However, it could be argued that most Māori social work methods are underpinned by tikanga Māori as a theoretical basis. It is important to note that Māori social workers are constantly developing new and diverse theories about their practice and can often take an 'eclectic' approach, using both Māori and non-Māori theories (Hollis-English, 2012). 'Tikanga Māori such as whakawhanaungatanga, wairuatanga (spirituality) and aroha are all fundamental aspects of Māori social work methods, are vital to their relationship with clients and also their approach in the organisational environment' (Hollis, 2006, p. 86).

The following are a selection of current Māori theories that inform social work practice.

\section{Kaupapa Māori Theory}

The theoretical approach, known as Kaupapa Māori Theory has been described as the 'conceptualising of Māori knowledge'. It is a theory that validates Māori knowledge and is derived from Te Ao Māori (Nepe, 1991, p. 15). It has been derived from a foundation of Kaupapa Māori and Mātauranga Māori (Pihama, 2001), and was created as an 'intervention strategy', existing to critique and transform praxis through conscientisation (Smith, 1997).

Graham Hinengaro Smith originally developed Kaupapa Māori Theory within the education context for teaching and research. Smith produced a framework with six principles or elements. They are: Tino Rangatiratanga the principle of self-determination; Taonga Tuku Iho the principle of cultural aspiration; Ako Māori the principle of culturally preferred pedagogy: Kia piki ake i ngā raruraru o te kainga the principle of socio-economic mediation; 
Whānau the principle of extended family structure; and Kaupapa the principle of collective philosophy. Since the theory's formation, numerous Māori theorists and scholars have enhanced and extended it, using it as a tool for guiding research and practice (Bishop, 1995, 1996, 2003; Cram \& Smith, 2004; Eketone, 2008; Smith, G., 1997, 2002; Smith, L. T., 1999; Pihama, 2001; Penetito. 2005; Walker, S. 1996).

\section{Âta - the principle of growing respectful relationships}

Pōhatu (2005) introduced the principle 'āta' specifically for the social services as a transformative approach for Kaupapa Māori initiatives. It is about building and looking after relationships and can support practitioners with understanding relationships and well-being when interacting with Māori. Pōhatu advances the argument that cultural underpinnings of whenua and whakapapa are imperative to ensure cultural transmission and acquisition. $\bar{A}$ ta has been described by Pōhatu (2005) as a key element of ngā take pū (principles) and is seen as a 'behavioural and theoretical strategy' for building and maintaining relationships. This principle is particularly relevant to the analysis of Māori social work practice and experiences as it helps to understand, '... how these domains function and interconnect, [and] suggest cultural approaches of how they may be safely navigated' (Pōhatu, 2005, p. 2).

\section{Te reo me ōna tikanga}

Pihama describes te reo me ōna tikanga as a central element of Kaupapa Māori theory, but it can be described as a theoretical approach. She states: 'The positioning of te reo me ona tikanga as central in Kaupapa Māori theory is not simply a theoretical statement but it is a part of the lived realities of many Māori people,' (Pihama, 2001, p. 115). This element is derived out of the importance of understanding the role they play as everyday aspects of the lives of Māori people and not just a theoretical statement. This element developed through an acknowledgement of the language loss Māori experienced within the education system in the 19th and 20th centuries, and a commitment by many Māori families to support their fluent speakers and commit to the development and involvement in Kura Kaupapa Māori. From Pihama's views, Kaupapa Māori theory encourages the use and understanding of te reo Māori and tikanga Māori for the benefit of Māori whānau and community development.

\section{Māori advancement theory}

Advancing Māori health, well-being or development is not just about targeting single issues but must contribute in a more general way to Māori advancement and Māori development (Eketone, 2004, p. 127).

Mason Durie's discussion of Māori advancement and development can also be used as an appropriate theory to underpin Māori social work practice (Durie, 1998a; 1998b). Durie states that the ultimate goal for Māori self-determination concerns the advancement of Māori as Māori and protecting the environment for future generations. He states that Māori advancement, in the context of self-determination, has three key dimensions. First, it is about improving the economic, social and cultural well-being and identity of Māori, both at an individual and a collective level. His second point about Māori advancement is that:

It also touches on the dimension of power and control, again at individual and group levels. Māori advancement is about the better self-management of natural resources, greater productivity of Māori land, the active promotion by Māori of good health, a sound education, enhanced 
usage of Māori language, and decision-making that reflects Māori realities and aspirations (M. Durie, 1998a, p. 4).

Durie's final dimension of Māori development is 'change'. He states:

Cultural fossilisation is not consistent with the spirit of development; and even though traditional values and knowledge have important lessons for today and offer some clues for the future, Māori self-determination is not about living in the past (Durie 1998a: p. 4).

\section{A Māori-centred theory}

Durie was influential in developing another theoretical approach that is relevant to Māori social work theory and practice. A Māori-centred theory was developed out of a philosophical view that the future development of Māori knowledge must consider current Māori worldviews and acknowledge the diverse nature of contemporary Māori society. The theory, described by Cunningham in relation to research, applies to research where Māori are significant participants, the main researchers, and most importantly where Māori analysis takes place (Cunningham, 2000). The production or the end result will be Māori knowledge. What differentiates this approach from others is that 'the result is measured against mainstream standards' (Cunningham, 2000, p. 65). The project will be undertaken through a mainstream organisation with overarching control of the project and some aspects of the methods would be mainstream as well as Māori. This theory applies to Māori social work that takes place by Māori, with Māori whānau within a mainstream organisation (or arguably with mainstream control, such as the New Zealand Government). Durie describes the practical implementation of the theory within the health context:

Services designated as Māori health services should be measured according to agreed upon outcome measures which make sense to Māori. Similarly, assessment measures should be more than a simple statement about DSMIV categories. They should also be capable of measuring the degree to which cultural and spiritual factors are associated with the problem (Durie, 1999, p. 10).

\section{Native theory}

[Native Theory is] the right of indigenous people to make sense of their time and place in this world' (Russell 2000. p. 10).

Native theory provides another way of explaining Māori practices and ways of being. Eketone explains that the comments above may seem to state the obvious, 'What it infers, however, is that indigenous people do not need the West to acknowledge, research or record their knowledge for it to be valid and useful in research, in practice and in life' (Eketone, 2004, p. 18). Russell introduced Native theory as a research approach that allows Māori researchers to undertake projects for Māori people, using Māori processes, and using terms that may not be appropriate or acceptable from a Western perspective (Eketone, 2004).

\section{A Mana Enhancing approach}

While a Mana Enhancing approach is not necessarily viewed as an explanatory theory, it can be applied directly to social work as an intervention theory. Ruwhiu (2001) describes mana as a key concept for social service development as it 'acts as the cultural adhesive that cements together those various dimensions (spiritual, natural, human) of Māori culture and society' 
(Ruwhiu, 2001, p. 60). He then explains that mana-enhancing behaviour is about ensuring that interactions between the spiritual, physical and natural realms are advantageous. Social workers, both Māori and non-Māori, can benefit from the understanding that every person has mana and can increase and share mana with others. Ruwhiu also describes how mana can also be reduced, lost or negatively affected by others.

In practice situations, this profession deals continuously with people who often experience trauma, pain, grief, loss, separation and disappointment. Subsequently, our work centres on mana-building strategies and techniques. The reciprocity is that as people heal themselves, those who are supporting them also experience 'mana enhancement' (Ruwhiu, 2001, pp. 60-61).

Therefore, social workers, as well as whānau they work with, should benefit from this particular approach to their practice.

\section{Tikanga Māori theory}

As discussed above, Kaupapa Māori theory contains many aspects of tikanga Māori. It is important to note that not all Māori social workers report using Kaupapa Māori theory to guide their work. Some refer to tikanga Māori as their underpinning theory. My own research with Māori social workers found:

There was an overall consensus among participants that the methods they use are embedded within tikanga Māori; therefore, they do maintain the theories of the past and tikanga Māori underpins the participant's methods (Hollis, 2006, p. 86).

However, many of the same concepts or customs of kaupapa Māori theory are referred to, such as whanaungatanga and whakapapa, te reo Māori and the Treaty of Waitangi. 'In order to assess the practices, processes and theories used by Māori in the social work field, one should primarily develop an understanding of ngā tikanga before anything else' (Hollis, 2006, p. 97).

While this is in no way an exhaustive list of Māori theories, these theories reflect the current evidence-based practice and theoretical approaches of many Māori social workers around the country. Kaupapa Māori Theory has been developing over the last three decades and is widely used, however theoretical approaches such as āta, te reo me ōna tikanga and Native theory have provided practitioners with specific tools and validation of their methods. Durie's Māori Advancement theory and Māori-centred theory have given Māori a higher level of macro-analysis and has enabled many Māori to work using tikanga within, but not exclusively in mainstream organisations. Finally, tikanga is a valuable and valid theoretical discourse that contains the knowledge for Māori to practise in any given situation and informs much of what practitioners do, when working with whānau Māori. The following methodology describes how I engaged with Māori social workers, with this literature behind me, to understand more fully which theories and models are informing their practice.

\section{Methodology and research design}

This research was guided by Kaupapa Māori theory and a narrative approach to qualitative research. The sample was purposive with a distinct section of the Māori social work popu- 
lation. The criteria for the participant selection included both:

- Māori - self-identifies as Māori in their own terms

- Social worker - holds a professional social work qualification, is currently in a professional social work position or has been in the past.

Twenty participants were sought for the research; however 26 Māori social workers that fitted the sample criteria elected to be involved in the research project.

In previous research into 'Māori methods of social work practice', I found that often Māori social workers would describe their processes or practices as opposed to 'methods' (Hollis, 2006). Therefore, for this project it was important not to assume that participants identified with one standardised method of practice. While age was not a sample requirement, it became evident that the participants that came forward were not school-leavers (i.e. young social workers who moved straight from high school to social work training and then on into practice). All but one participant had 10+ years of social work experience.

Participants were interviewed using a questionnaire for guidance, either individually or in a group in accordance with their wishes. Māori methods of research were undertaken, such as whakawhanaungatanga, karakia, mihimihi, kai, waiata, koha and other processes that were deemed appropriate by the participants and myself. Participants also reviewed their transcripts for approval and were gifted a copy of the research on completion.

\section{Research findings: Values and beliefs}

When discussing Māori social work theories, values and beliefs are key elements of the theories and processes that guide Māori social work practice and the use of social work models. Values, beliefs, theories, practices and protocols were described by participants whose awareness of their belief systems led to a better understanding of how to implement theoretical processes in a real-life scenario. In this research, values were often implied in their general comments about their interactions with Māori families. The first example showed how the participant's work was influenced by the values and principles of Te Ao Māori.

'Māori' in my view is a word that implies the connection to my culture and not ethnicity, and so in my practice I work from a cultural/spiritual worldview and values and principles of Te Ao Māori as I perceive and interpret them.

This Māori social worker described how using the term 'Māori' has cultural connotations and implied that one can be 'culturally Māori', which differs substantially from someone who is ethnically Māori. She described how these beliefs come from Te Ao Māori and are unique to the way she perceived them. Some of the participants explicitly discussed their values. One participant described what her values meant to her.

I think we need to keep challenging this notion of social work. You know as tangata whenua (indigenous) we've been doing it. We've been doing counselling, social work, community development, all of those issues are within the context of us working with whānau (extended family), hapū (sub-tribe) and iwi (tribe), but we just haven't got those labels. It's tautoko (support), āwhina (assistance), aroha (love), tika (correct), pono (truth).

This is, connected to the 'Dynamics of Whanaungatanga' course, developed in association with Pa Henare-Tate (Tate \& Paparoa, 1986; Tate, 2010). However, tangata whenua do not 
always name these concepts when they use them. In her words, '... challenging the notion of social work' should include the naming of these concepts and an awareness of what they mean to Māori social workers. Other participants have different ways of describing their values.

I bring to this unit my own whakaaro (opinion), and a particular take pū (principle), ... and I live with those in my personal life and as I study too I apply them. So I bring that. The processes for me are having that structure and take pū and I am able to work with that.

This participant describes take pū in terms of the processes she uses with clients and refers to the take pū described and articulated by Taina Pōhatu (2003). While one Māori social worker's values come from a particular worldview, they are applicable for working with many cultural groups.

We have those values from Te Ao Māori, from our whānau, our hapū and iwi. Mine are different from hers or his but they are still fundamentally the same things: a belief in protecting our taha Māori, valuing Te Reo (the Māori language), our tino rangatiratanga (self determination) and decision-making... We might have different ways of putting this into action or describing it, but I think the values coming from Te Ao Māori are unique to us.

This comment shows how the values stemming from Te Ao Māori are continuous in both the participant's every-day and professional life. Finally, another participant discusses processes but also describes how values influence the processes she uses. Following this, she refers to the text Exploring Māori Values (Patterson, 1992).

Again, in my view, processes are a step-by-step guide of rituals where the values of Te Ao Māori sit. Values and principles have a beginning or source and the processes are rituals to remember why or who I am... So it is the values that guide my processes within my mahi (work).

\section{Theories}

Very few participants named the theories they use or described them in extensive detail. However, some participants discussed the concept of theoretical underpinnings and used examples to emphasise their ideas. One participant described the theories that underpin his work in the following way:

You know we talk about theories, for me I am guided by Māori theories, kaupapa Māori (Māori philosophy) theory, but also those traditional ones. They don't all have flash names like 'cognitive behavioural theory', but there are things that we all follow and know what is meant when we hear the words 'tino rangatiratanga', that's an idea, a way of thinking that is underpinned by values and has processes, I think that makes it a theory. So yeah, my work is underpinned by tino rangatiratanga theory.

While we can discuss the idea of 'Māori theories' as well as Kaupapa Māori theory, tino rangatiratanga theory is seen as something distinctive. The participant's remarks indicate how Māori social workers see their practice as being underpinned by multiple theories. Another participant added her own perspective to this discussion.

There are things we do that I think are theories but we don't call that. We call them whanaungatanga (kinship relationships), aroha but they are much more than that; they are theories about how people should interact with others. But then we have things like, 
trying to make our workplace not tokenistic, make it really incorporate taha Māori into the workplace, that part of our mahi is from a belief system, there are theories around that and processes that come out of it. We haven't labelled our mahi completely using Pākehā (nonMāori) terms, but should we?

Theories can encompass all aspects of one's work from the implementation of processes to workplace interaction. One participant describes how his position includes educating colleagues about Te Ao Māori or the Māori world. This participant uses a whakataukī (proverb) 'Matua, whakapapa i tōu marae ka whakapai ai i te marae o te tangata' to underpin his theoretical approach to his mahi.

I have been requested by my organisation to seek people who have knowledge of things that are Māori as I have been informing the organisation that we cannot use Māori words in our planning of holiday programmes or vision/mission statements if we don't understand what the meaning behind the word is. 'Fix our own back yard up first before we go out and work with others'.

Tīkanga has been described by a number of participants as a way to explain the implementation of values in a practical sense. While the following example relates to the competency assessment process it refers to a way of understanding and explaining a Māori way of doing things through tīkanga:

We were talking about how many Māori are doing the competency test through the Pākehā system rather than the Māori because their view is that the Māori one is a lot harder. But it's not. Māori competency tests are a lot easier. It's a process that is based on tīkanga values, kanohi ki te kanohi (being face-to-face).

Tîkanga can then be understood as being an explanatory theory as well as an intervention theory. The following example emphasises this:

Our organisation saw it fit that something had to be developed in terms of tīkanga and the practices because it was not deliberate ignorance but there was a lot of ignorance across our colleagues, our non-Māori. And so we developed Tīkanga Best practices. So if there is any Kaumātua or kuia on the wards, if we can't get hold of the chaplain, there are many things, tikanga things that they are needed for and we might have to come in and do if they're unavailable.

While many participants noted that their practice is underpinned by tīkanga (or tīkanga theory) they did note that not all Māori whānau have the same worldviews and philosophies:

So as tangata whenua practitioners in our contact with tangata whaiora (clients) and their families, if they haven't been brought up within tīkanga of their areas as Te Ao Māori, they're also at loggerheads when we say to them 'how would you like to open this whānau hui? Would you like to open it with a karakia?' they say 'what? We don't have time for that shit' we just want to get on with the process. And so already your practice is being constrained and almost jeopardised by the fact that a lot of our people have been so colonised.

Another participant explains the need for Māori theories:

Our kawa are different, our tīkanga are different, and our languages are different if we look at dialectical shifts ... We are purporting those values, those tîkanga, within their knowledge 
base. Yet when you go into practicum very few agencies, in my opinion, practice Kaupapa

Māori or Kaupapa tangata whenua.

This quote, discussing the contrasts between Māori theories and processes with the processes of social service organisations, shows that there are many challenges for Māori social workers and social service organisations in Aotearoa New Zealand.

\section{Summary and implications of this research}

Māori social workers used tīkanga Māori to describe the positive processes they used in practice. They claimed that these processes are underpinned by the values and beliefs of Te Ao Māori. Many of the terms used to describe Māori social work were described as values and practices. An example of the dual interpretation is: tika and pono. These Te Ao Māori values encapsulate principles of honesty, integrity and respecting tìkanga. However, these values are also transformed into 'verbs'. They are translated into actions by the social worker taking the required care to be truthful and honest with whānau and clients.

Māori social workers also regard several other practices as successful. This includes Māori processes at locations such as a marae, utilising the skills of Māori experts, such as kaumātua, and engaging with the pōwhiri process. Some Māori social workers use established 'models' such as Te Whare Tapa Whā or Poutama. Others have created models that are appropriate to their current place of employment, such as Tîkanga Best-Practice. However, there are challenges for Māori social workers themselves. First, Māori social workers are challenging the notion of what the term 'Māori' actually means. Many are referring to the term 'tangata whenua' meaning indigenous, as this more adequately reflects their position in the world according to many of the research participants. There are challenges for Māori and indigenous social workers when their indigenous families have been so colonised that they may not be open or interested in Māori theories and processes and more worryingly there are many challenges for Māori social workers within social service organisations that are unsupportive of Māori theories. However, this research shows that many Māori social workers are taking the challenges head-on and are committed to implementing Mãori theories and methods within New Zealand social services.

\section{Implications of this research for indigenous social work development}

A cardinal point is that Māori social workers need support in developing their cultural knowledge in order to continue critically integrating concepts of identity, theory and tikanga into practice. This support should come from training institutes, social service organisation's management structures and from all social workers that are dedicated to providing indigenous families with more appropriate support. Greater support increases one's ability to justify practices based on a Māori worldview. Training institutes, social service organisations and Māori social workers themselves need to promote the importance of developing Māori and indigenous theories so that all social workers, not just indigenous ones, understand their complexity and importance for working with indigenous families. This will allow indigenous practitioners to work in culturally appropriate and informed ways with indigenous families, without the pressure to conform to non-indigenous theoretical discourse.

Implicit in this research is the diverse realities of Māori families and the diverse knowledge, skills and values needed to work with them. Māori social workers are developing their skills to a level that enables them to meet the needs of all types and kinds of Mãori 
families. Social services in Aotearoa can better support the use of Māori theories through increasing their understanding of indigenous theories and their benefit for improving the well-being of indigenous peoples. This research validates Māori social work practices and can provide insight into how Māori social workers practise in contemporary Aotearoa. Māori social workers need to have confidence in their methods, knowing that their processes are underpinned by theoretical discourse and do lead to positive outcomes for Māori families.

\section{Implications for organisations}

While many social service organisations have made considered efforts to implement the Treaty of Waitangi and other culturally appropriate practices, Māori practitioners have experienced a variety of environments, some that are supportive of tīkanga Māori and some that are not. In order for organisations to be aware of their level of cultural capabilities - as an organisation, not reliant on individual employees - they need to establish a system of organisational review. An example of this is participating in the Te Wana Quality Improvement Programme which is a quality improvement programme for Māori, Pasifika, youth, primary health, mental health, and community social service organisations or an NGO [non-government organisation] (Te Wana, 2010). The establishment of this type of system could enable the organisation to continually review their internal processes around implementing tīkanga and through this, adequately support Māori social workers.

\section{Conclusion}

Theoretical discourse in the world of Māori social workers enables one to grow and develop their practice, leaning on ancestral knowledge and valuing the skills that are gained through understanding tikanga in a contemporary context. Through the development of theories, both within the social work profession and from other areas, such as education, health and research, Māori social workers are able to validate their processes and work with Māori families in ways that support and promote Te Ao Māori, enhancing their well-being as Māori in contemporary times. This article draws on research with Māori social workers who have described the theories they use and the benefits for practice. Ultimately, Māori social workers continue to develop their practice frameworks in ways that result in improved outcomes for Māori families and communities by drawing on traditional knowledge.

\section{References}

Bishop, R. (1995). Collaborative research stories: Whakawhanaungatanga. A thesis submitted for the degree of Doctor of Philosophy at the University of Otago, Dunedin, New Zealand. Thesis (PhD), University of Otago, 1995.

Bishop, R. (1996). Collaborative research stories: Whakawhanaungatanga. Palmerston North: Dunmore Press.

Bishop, R. (2003). Changing power relations in education: Kaupapa Māori messages for 'mainstream' education in Aotearoa/New Zealand. Comparative Education, 39(2), 221-238.

Cunningham, C. (2000). A framework for addressing Māori knowledge in research, science and technology. Pacific Health Dialog, 7(1), 62.

Cram, F. \& Smith, L. (2004). Māori women talk about accessing health care. He Pukenga Kōrero, 7(2), 1-8.

Durie, M. (1998a). Te mana, te kawanatanga: The politics of Māori self-determination. Auckland: Oxford University Press.

Durie, M. (1998b). Whaiora: Māori health development (2nd ed.). Auckland: Oxford University Press.

Durie, M. H., \& Mental Health Foundation of New Zealand. (1999). Māori culture identity and its implications for mental health services. Auckland: Mental Health Foundation of New Zealand.

Eketone, A. D. (2004). Tapuwae: Waka as a vehicle for community action. A thesis submitted for the degree of Master of Consumer and Applied Sciences at the University of Otago, Dunedin, New Zealand. Thesis (M CApSc), University of Otago, 2005.

Eketone, A. D. (2008). Theoretical underpinnings of Kaupapa Māori directed practice. MAI Review, (1), 1-11.

Hollis, A. N. R. (2006). Pūao-te-Ata-tū and Māori social work methods. A thesis submitted for the degree of Master of Arts at the University of Otago, Dunedin, New Zealand. Thesis (MA), University of Otago, 2006. 
Hollis-English, A. N. R. (2012). Māori social workers: Experiences within social service organisations. A thesis submitted for the degree of Doctor of Philosophy at the University of Otago, Dunedin, New Zealand. Thesis (PhD), University of Otago, 2012.

Nepe, T. (1991). E hao e tēnei reanga te toi huarewa tipuna. Unpublished MA thesis, Auckland University.

Patterson, J. (1992). Exploring Māori values. Auckland: Dunmore Press.

Penetito, K. H. (2005). Me mau kia ita ki te tuakiri o te whānau ma te whānau e tipu ai: Whānau identity and whānau development are interdependent. A thesis submitted to the Auckland University of Technology in partial fulfilment of the degree of Master of Arts, 2005.

Pihama, L. (2001). Tīhei mauri ora: Honouring our voices: Mana wahine as a kaupapa Māori: Theoretical framework. Thesis (PhD, Education) University of Auckland, 2001.

Pōhatu, T. (2003). Māori world-views: Source of innovative social work choices. Retrieved 22 July, 2010 from www. kaupapamaori.com.

Pōhatu, T. (2005). Áta: Growing respectful relationships. Retrieved 22 July, 2010 from www.kaupapamaori.com.

Russell, K. (2000). Landscape. Perceptions of Kai Tahu I Mua, Äianei, Ä Muri Ake. A thesis submitted for the degree of Doctor of Philosophy in Anthropology at the University of Otago, Dunedin, New Zealand.

Ruwhiu, L. (2001). Bicultural issues in Aotearoa New Zealand social work. In M. Connolly (Ed.). Social Work in New Zealand: Context and Practice. Oxford University Press: Auckland.

Smith, G.H. (1997). The development of kaupapa Māori. Theory and praxis. Thesis (PhD, Education) University of Auckland, 1997.

Smith, G. H. (2002). The development of kaupapa Māori. Theory and praxis. University of Auckland. International Research Institute for Māori and Indigenous Education. Thesis (PhD, University of Auckland, Education) University of Auckland, 1997, Auckland, N.Z.

Smith, L. T. (1999). Decolonizing methodologies: Research and indigenous peoples. Dunedin: Zed Books University of Otago Press.

Tate, H. A. (2010). Towards some foundations of a systematic Māori theology. He tirohanga anganui ki ètahi kaupapa hōhonu mō te whakapono Māori. A thesis submitted in fulfillment of the requirements for the degree of Doctor of Philosophy, Melbourne College of Divinity. Melbourne.

Tate, H. A. \& Paparoa, T. (1986) (Eds.). Karanga Hokianga. Hokianga: Motuti Community Trust.

Te Wana. (2010). Accreditation programme. Retrieved from: http: / / tewana.org.nz/.

Walker, S. (1996). Kia tau te rangimarie: Kaupapa Māori theory as a resistance against the construction of Māori as the other. Thesis (MA, Education), University of Auckland, 1996. 